\title{
Assessment of Socio-economic Status of Farmers and Distribution of Buffalo Population in the Mahakaushal Region of Madhya Pradesh
}

\author{
Rajesh Kumar Vandre ${ }^{1}$, Shrikant Joshi ${ }^{1}$, Mohan Singh Thakur ${ }^{*}$, Madhu Sudhan Tantia ${ }^{2}$, Rekha Sharma ${ }^{2}$, \\ Ajit Pratap Singh ${ }^{3}$, Akhilesh Pandey ${ }^{1}$, Vaishali Khare ${ }^{1}$, Mona Sharma ${ }^{1}$ and Asad Khan ${ }^{1}$ \\ ${ }^{1}$ Department of Animal Genetics and Breeding, Nanaji Deshmukh Veterinary Science University, Jabalpur, Madhya Pradesh, \\ INDIA \\ ${ }^{2}$ ICAR-National Bureau of Animal Genetic Resources Karnal-132001, Haryana, INDIA \\ ${ }^{3}$ Animal Biotechnology Center, Nanaji Deshmukh Veterinary Science University, Jabalpur, Madhya Pradesh, INDIA
}

*Corresponding author: MS Thakur; E-mail:drmohansingh@gmail.com

Received: 30 June, 2021

Revised: 10 July, 2021

Accepted: 18 July, 2021

\begin{abstract}
The study of socio-economical status of the farmers and distribution of buffalo population were conducted at Mahakaushal region of Madhya Pradesh. Mahakaushal, a region of central India, lies in the upper or eastern reaches of the Narmada river valley in the Indian state of Madhya Pradesh. Data were collected through farmer's interview from target districts. Survey was indicated that the buffalo population was distributed in entire Mahakaushal region of the Madhya Pradesh particularly in Jabalpur, Mandla, Dindori, Seoni districts and in parts of adjoining districts including Naringhpur, Balaghat, Chhindwada, Katani and Umaria. The overall socioeconomic status of farmers was poor in all the districts. The annual income of farmers of Jabalpur and Mandla districts was slightly higher than the farmers of Dindori and Seoni districts; it might be due to slightly higher irrigated lands (1-3 acres) and literate family members (4-5). The farmers in Mahakaushal region mainly depends upon the pasture feeding for their livestock. The place, where animals were gathered during grazing is known as Khirka. The mating normally occurs during grazing. It was revealed that on an average 90 percent farmers housed their animals only at night while 10 percent of farmers housed them both day and night. In 98 percent animal houses, floor was kachcha type. In about 95 percent animal house had no drainage system. In 100 percent animal house had kachcha type of drainage. The survey was the first attempt to study the demographic and geographical distribution in Mahakaushal region of Madhya Pradesh.
\end{abstract}

\section{HIGHLIGHTS}

(0 Socioeconomic status of farmers was poor in majority of survey districts.

(0 Mainly Kachcha type of housing was followed in all the survey districts.

(0 The farmers livestock depends upon mainly pasture grazing.

Keywords: Breeding tract, Buffalo, Socioeconomic, Survey

India is largely dependent on agriculture, with agriculture providing financial assistance for around 70-75 per cent of the people. Cattle or Buffalo are kept as an auxiliary to crop cultivation for milk production, mechanical power for different agricultural activities, village transit, irrigation and manure generation. In general, the animals are fed agricultural leftovers and crop wastes. Landless, Small and marginal farmers, as well as landless laborers, are mainly accountable for animal husbandry. The landless and small farmers are mainly depending upon the livestock for supplemental income. Thus, identifying strengths and weaknesses, as well as understanding of present management practices may be useful in developing

How to cite this article: Vandre, R.K., Joshi, S., Thakur, M.S., Tantia M.S. Sharma, R., Singh, A.P., Pandey, A., Khare, V., Sharma, M. and Khan, A. (2021). Assessment of Socio-economic Status of Farmers and Distribution of Buffalo Population in the Mahakaushal Region of Madhya Pradesh. J. Anim. Res., 11(04): 711-716.

Source of Support: None; Conflict of Interest: None 
appropriate intervention strategies. Buffaloes in India are third major contributors in the livestock population and largest producers of milk and meat in the country, although their contribution to draught animal power is relatively low but buffaloes are useful for pulling heavy loads at a low speed. In Madhya Pradesh, as per the $19^{\text {th }}$ livestock census total buffalo population was 8.1 million out of which more than 90 per cent population are non-descript type (BAHFS, 2020).

The number of specified breeds and lesser known breeds are expected to be about 5 to 10 per cent of the total buffalo population in the country. Rest of the buffaloes are nondescript type and have extremely variable composition being either non-descript or crosses among various breeds and cannot be categorized in any other well-established breed. There is general concern that the genetic variation within the few domestic animal species is disappearing through breed substitution and inter-breed crossing. Any reduction in the diversity of genetic resource narrows the scope to respond to selective breeding (Sethi and Kala, 2005). The present study has been planned to assess the demographical and geographical distribution existing local buffalo population and socioeconomic status of farmers in Mahakaushal region of Madhya Pradesh.

\section{MATERIALS AND METHODS}

The survey was planned to study the demographic and geographical distribution of buffaloes in Mahakaushal region of Madhya Pradesh. During the survey, the concentration of buffalo population was taken into consideration along with socioeconomic status of the framers. This study reveals the information on the socio-economic status of farmers (through face to face interview), their livestock management practices.

\section{RESULTS AND DISCUSSION}

\section{Breeding tract}

The breeding tract of buffaloes under the present study has been shown in the figure 1 . The buffalo population was distributed in entire Mahakaushal region of the Madhya Pradesh particularly in Jabalpur, Mandla, Dindori, Seoni districts and in parts of adjoining districts including Naringhpur, Balaghat, Chhindwada, Katani and Umaria.
The animals of buffalo population under study were mainly present in the interior areas of districts and villages which are close to the forest area where hardly any facility for A.I. was available. During the survey, it was found that the buffalo population was in the pure form because the mating of animals was mainly based on natural service and A.I. was rarely preferred by the farmers.

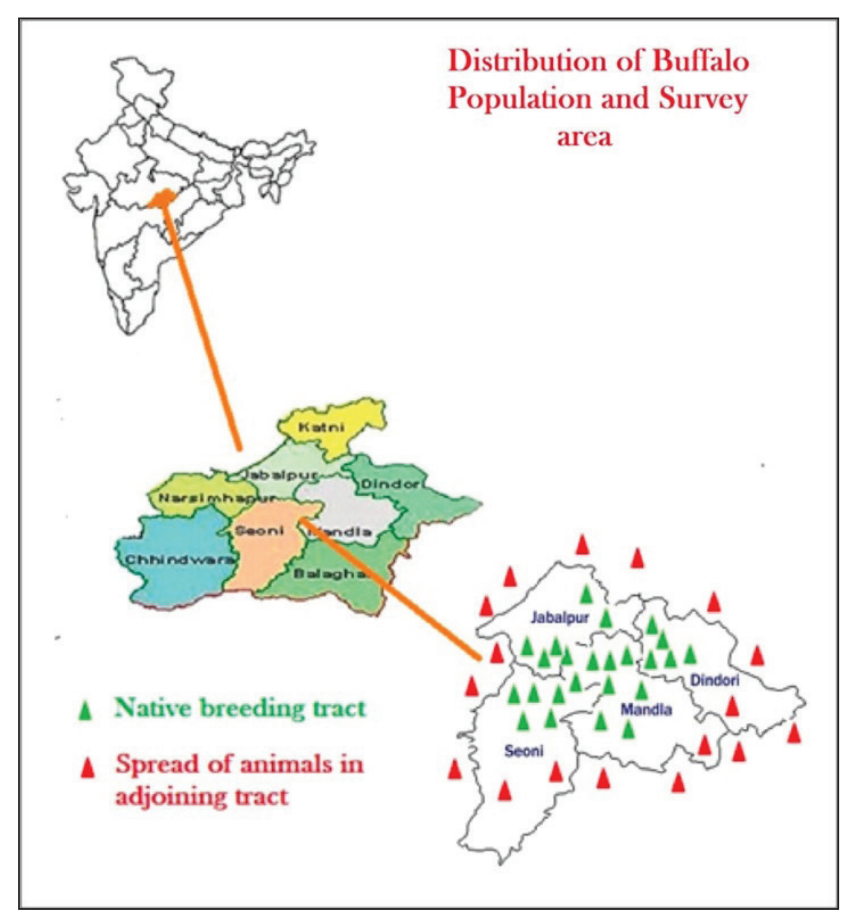

Fig. 1: Distribution of buffalo population in Mahakaushal region of M.P.

\section{The native environment and climate}

Mahakaushal, a region of central India, lies within the upper or eastern reaches of the Narmada river valley within the Indian state of Madhya Pradesh. The region lies in between Latitude: $23^{\circ} 08^{\prime} 60.00^{\prime}$ N Longitude: $79^{\circ} 55^{\prime} 58.80^{\prime \prime} \mathrm{E}$. The Mahakaushal region is also known as Maikal hill zone. The climate of the Mahakaushal is humid subtropical, as is typical of north-central India. The geography and climatic description of districts of the breeding tracts is presented in table 1 .

\section{Soil, feed and fodder}

The overall soil in entire Mahakaushal region is Black type. It was observed that wheat, paddy, maize, jowar, 
Table 1: Geographical and climatic description of the breeding tract

\begin{tabular}{|c|c|c|c|c|}
\hline \multirow[t]{2}{*}{ Particulars } & \multicolumn{4}{|c|}{ Districts } \\
\hline & Jabalpur & Mandla & Dindori & Seoni \\
\hline \multicolumn{5}{|l|}{ 1. Topography: } \\
\hline a. Latitude $(\mathrm{N})$ & $23^{\circ} 10^{\prime} \mathrm{N}$ & $22^{\circ} 06^{\prime} \mathrm{N}$ & $22^{\circ} 94^{\prime} \mathrm{N}$ & $22^{\circ} 08^{\prime} \mathrm{N}$ \\
\hline b. Longitude (E) & $79^{\circ} 56^{\prime} \mathrm{E}$ & $80^{\circ} 36^{\prime} \mathrm{E}$ & $81^{\circ} 07^{\prime} \mathrm{E}$ & $79^{\circ} 57^{\prime} \mathrm{E}$ \\
\hline c. Height (MSL) & $411 \mathrm{~m}$ & $624 \mathrm{~m}$ & $678 \mathrm{~m}$ & $612 \mathrm{~m}$ \\
\hline d. Area (Sq. Km.) & 367 & 8771 & 6128 & 8758 \\
\hline \multicolumn{5}{|l|}{ 2. Climatic condition: } \\
\hline a. Temp. (Max.) & $47^{\circ} \mathrm{C}$ & $43^{\circ} \mathrm{C}$ & $43.6^{\circ} \mathrm{C}$ & $40.3^{\circ} \mathrm{C}$ \\
\hline b. Temp. (Min.) & $8^{\circ} \mathrm{C}$ & $10^{\circ} \mathrm{C}$ & $3.1^{\circ} \mathrm{C}$ & $11.3^{\circ} \mathrm{C}$ \\
\hline c. Annual Rain fall & $1279.5 \mathrm{~mm}$ & $1392 \mathrm{~mm}$ & $1450 \mathrm{~mm}$ & $1323 \mathrm{~mm}$ \\
\hline d. Humidity (Range) & $54-82 \%$ & $41-84 \%$ & $25-79 \%$ & $34-88 \%$ \\
\hline
\end{tabular}

Source: https://www.timeanddate.com/weather/india/.

Table 2: Age wise and sex wise distribution of buffalo population in Mahakaushal region

\begin{tabular}{|c|c|c|c|c|c|c|c|c|c|}
\hline \multirow{3}{*}{ Districts } & \multicolumn{2}{|c|}{ Up to 1 year } & \multicolumn{2}{|c|}{ 1-3 year } & \multicolumn{4}{|c|}{ Above 3 years } & \multirow[t]{3}{*}{ Total } \\
\hline & \multirow{2}{*}{ Male } & \multirow{2}{*}{ Female } & \multirow{2}{*}{ Male } & \multirow{2}{*}{ Female } & \multicolumn{2}{|r|}{ Male } & \multicolumn{2}{|c|}{ Female } & \\
\hline & & & & & Bull & Bullock & Milk & Dry & \\
\hline Jabalpur & 246 & 458 & 305 & 678 & 56 & 25 & 956 & 459 & 3183 \\
\hline Mandla & 312 & 567 & 208 & 718 & 35 & 12 & 683 & 359 & 2894 \\
\hline Dindori & 205 & 472 & 315 & 523 & 48 & 11 & 729 & 390 & 2693 \\
\hline Seoni & 106 & 380 & 158 & 470 & 21 & 8 & 486 & 289 & 1918 \\
\hline Total & 869 & 1877 & 986 & 2389 & 160 & 56 & 2854 & 1497 & 10688 \\
\hline Per cent & 8.13 & 17.56 & 9.22 & 22.35 & 1.49 & 0.52 & 26.70 & 14.00 & \\
\hline
\end{tabular}

etc. cereals were grown. The farmers mainly depend upon the pasture grazing for their livestock. There were only few farmers (1-2 \%) that grow fodders (Barseem, Lucerne etc.) for their animals. The grass was available mainly during the rainy season and also in winter season. It was observed that grasses such as samai, gunhari, kandhia etc. were given to livestock as per availability in the area. The wheat straw and dry grasses were fed to animals during summer season.

\section{Demographical and geographical distribution}

In the present study, total 10688 animals were covered under demographic survey in the Mahakaushal region of Madhya Pradesh. It was observed that in the whole breeding tract farmers were maintaining good number of buffalo animals. The age and sex wise population distribution of buffalo population surveyed in Mahakaushal region has been presented in table 2 . In all the age groups, the population of female was larger than that of male. It could be due to the fact that buffaloes female animals are mainly reared for milking purpose and buffalo bulls are not preferred for draught purpose (Table 2).

\section{Socio-economic status of farmers}

The information regarding the socioeconomic status of farmers of Jabalpur, Mandla, Dindori and Seoni districts have been obtained by random survey using questioners. The average agricultural status of farmers of these districts was comparable. The overall socioeconomic status of farmers was poor in all the districts. The annual income of farmers of Jabalpur and Mandla districts was slightly higher than the farmers of Dindori and Seoni districts; it 
Table 3: Agricultural status of farmers

\begin{tabular}{llllll}
\hline Attribute & Jabalpur & Mandla & Dindori & Seoni & Overall \\
\hline Agriculture holding (Acre) & $1-4$ & $1-3$ & $1-3$ & $1-2.5$ & 1 to 3.12 \\
Irrigated land (Acre) & $1-3$ & $1-2.5$ & $1-2$ & $1-2.25$ & $1-2.43$ \\
Annual Income (₹) & $15000-68000$ & $12000-65000$ & $10000-60000$ & $11000-62000$ & $12000-63750$ \\
Family members (No.) & $4-6$ & $5-6$ & $6-7$ & $5-6$ & $5-6.25$ \\
Male family members (No.) & $2-4$ & $2-3$ & $3-4$ & $2-3$ & $2.25-3.50$ \\
$\begin{array}{l}\text { Female family members (No.) } \\
\text { Literate members (No.) }\end{array}$ & $2-3$ & $2-3$ & $3-4$ & $2-3$ & $2.25-3.25$ \\
$\begin{array}{l}\text { Male members engaged in animal } \\
\text { husbandry (No.) }\end{array}$ & $4-5$ & $4-5$ & $2-4$ & $2-4$ & $3-4.5$ \\
$\begin{array}{l}\text { Female members engaged in animal } \\
\text { husbandry (No.) }\end{array}$ & $1-2$ & $1-2$ & $2-3$ & $2-3$ & 1.5 to 2.5 \\
No of houses covered (No.) & 300 & $1-2$ & $2-3$ & $1-2$ & $1.25-2.25$ \\
\hline
\end{tabular}

Table 4: Housing and feeding practices of buffalo population followed in Mahakaushal region

\begin{tabular}{|c|c|c|c|c|c|}
\hline Attribute & & $\%$ & Attribute & & $\%$ \\
\hline \multirow[t]{2}{*}{ Animal tide: } & Only night & 90 & Fodder & Fodder grown & $1-2$ \\
\hline & Day \& Night & 10 & & Pasture feeding & $98-99$ \\
\hline \multirow[t]{2}{*}{ Types of animal house } & Open & 15 & Feeding method: & Soaked & 5 \\
\hline & Close & 85 & & Raw & 95 \\
\hline \multirow[t]{2}{*}{ Types of construction } & Kachcha & 98 & Concentrate feeding & & 5 \\
\hline & Paucca & 2 & & & \\
\hline \multirow[t]{2}{*}{ Location of animal house } & Part of residence & 80 & Feeding at milking time & & 90 \\
\hline & Separate & 20 & Cleaning milk utensils & & 100 \\
\hline \multirow[t]{2}{*}{ Type of flooring } & Kachcha & 98 & Washing of udders before milking: & & 100 \\
\hline & Paucca & 2 & Grazing: & Distance & $2-3 \mathrm{~km}$ \\
\hline \multirow[t]{2}{*}{ Construction of wall } & Complete & 60 & & Time & 7 to $9 \mathrm{hr}$ \\
\hline & Half & 40 & Water adequacy: & & 80 \\
\hline \multirow[t]{2}{*}{ Hygiene of animal houses } & Clean & 45 & & & \\
\hline & Not clean & 55 & & & \\
\hline \multirow[t]{2}{*}{ Provision for drainage } & Yes & 5 & & & \\
\hline & No & 95 & & & \\
\hline Types of drainage & Kachcha & 100 & & & \\
\hline
\end{tabular}

might be due to slightly higher irrigated lands (1-3 acres) and literate family members (4-5). Agricultural Status of farmers of Dindori and Seoni districts was lower as compare to other two districts. The agricultural status of farmers of survey area has been presented in the table 3 .

\section{Housing, feeding and management practices}

The results of random survey regarding housing, feeding and management practices are presented in table 4. It was observed that mostly farmers housed their animals only at night $(90 \%)$ while very few farmers $(10 \%)$ housed their animals during day and night. This was more or less a general practice prevailing in all districts. The close housing system (85\%) was mainly followed than open housing system (15\%). The kachcha type of house and floor with half height wall (98\%) was mostly used for housing the animals. About the 80 per cent animals house was besides the resident of farmers and 20 per cent farmers had separate animal's houses. Most of the animal houses had no drainage system (95\%). The hygiene and sanitary condition of the animal houses was very poor. In agreement with the present findings, Chandran et al. (2019) reported more or less similar pattern of different managmental practices in breeding tract of Diara buffalo in the middle gangetic plains of Bihar, India. 
It was observed that only 1-2 per cent of farmers grown fodder in the breeding tract. The animals were mainly depends upon pasture feeding (98-99\%). The feeding with chaffed green fodder was less common (1-2\%). Raw feeding was practiced by 95 per cent farmers whereas soaked feeding was practiced by 5 per cent of the farmers in the targeted districts. As revealed by survey cooked feeding was not practiced at all. Feeding at the time of milking was practiced by majority of the farmers $(90 \%)$. It was observed that almost all the farmers were conscious about the hygiene and therefore, cleaning of milking utensils and washing of udders before milking was a common managemental practice (Table 4). The source of water for buffalo animals was river, nala, canals, well, ponds and tank. Water availability for animals was adequate except during the summer season. Overall adequacy of water was about 80 per cent. Sometimes problems aggravated at time of poor rainfall.

In general, pasture grazing was preferred by the farmers for their animals. The buffaloes in the region are commonly released for grazing in the morning and returned home in the evening from grazing land. The animals practically depend upon grazing the whole day in the forest area with nominal feeding of concentrates once a day at the time of milking. Buffaloes were taken for grazing immediately after morning milking or by about 7-8 A.M. and returned back to their home in the evening by about 6-7 P.M. The place, where animals were gathered during grazing is known as Khirka. The mating normally occurs during grazing. An animal attendant, known as Charwaha looks after the animals of entire village. During the summer, the animals roam freely in the Wardi system. It was observed that grazing land distance was $2-3 \mathrm{~km}$ from the villages. The young suckling calves of six months of age and above are also allowed for grazing with their mother by majority of farmers. In the breeding tract, the animals were depended upon pastures for their feeding. However, sometimes they were given bhusa and local grasses depending upon the availability. It was observed that very few farmers fed concentrate to their livestock. Concentrate was given to animals only during milking time. The concentrate fed to these animals included aata (flour), choker (bran) and sometime khali-chuni etc. Individual feeding rather than group feeding were practiced at the time of milking. Natural service practiced by majority of farmers. It was observed that in interior areas there was no any facility of A.I., so farmers depends upon natural breeding with common buffalo bull that was available in Khirka.

Similar findings of free grazing system was also reported as a major practice in buffaloes of Maharashtra (Kalyankar et al., 2008) and Galao strain of Nagpuri buffalo (Gubbawar et al. 2012). Kurrey (2015) reported that local buffaloes of Chhattisgarh plains were reared under semi intensive system of management and buffaloes were close to human dwellings. Jayashankar (2005) reported that the Gowli buffaloes were mainly maintained for milk production and also used for agricultural operations and transport. Practice of feeding concentrate to buffaloes varies in different parts of the country. Kalyankar et al. (2008) and Gubbawar et al. (2012) reported no concentrate feeding practiced and if offered, it is not as per the level of production in buffaloes of Maharashtra. Ali et al (2019) reported that some farmer offered the concentrate feeding to Puranthadi buffaloes which is in accordance with present study. Kurrey (2015) observed that the concentrate feeding was generally offered to local buffaloes of Chhattisgarhi during the advance stage of pregnancy and at early stage of lactation. Chandran et al. (2019) reported that $75.4 \%$ of animals were bred with Diara buffalo bulls available in the breeding tract. Natural service was done with the breeding bulls during grazing in several districts of Rajasthan (Gupta et al., 2008) and at Indore district of Madhya Pradesh (Ahirwar et al., 2010).

\section{CONCLUSION}

The study revealed that the buffalo population mainly distributed in Jabalpur, Mandla, Dindori, Seoni and adjoining parts of the districts. The Socioeconomic status of farmers was poor in majority of survey districts. The Kachcha type of housing was observed mainly in the suryed area. The farmers mainly depend upon the pasture feeding for their livestock. The present study was the first attempt for demographic and geographic survey of the Mahakaushal region of Madhya Pradesh.

\section{ACKNOWLEDGEMENTS}

The authors are thankful to the NBAGR, Karnal to carry out this research work under project and University authorities NDVSU, Jabalpur for providing all the necessary facilities to conduct the study. 


\section{REFERENCES}

Ahirwar, R.R., Singh, A. and Qureshi, M.I. 2010. A study of managemental practices in water buffalo (Bubalus bubalis) in India. Buffalo Bull., 29: 43-51.

Ali, S.S., Kuralkar, S.V., Ingawale, M.V., Waghmare, S.P., Manwar, S.J., Kataria, R.S. and Vohra, V. 2019. Phenotypic characterization, management and socio-economic impact of Purnathadi buffaloes. Indian J. Anim. Sci., 89(10): 11611166.

BAHFS. 2016. Basic Animal husbandry and fishery statistics, Government of India, Online: http://www.dahd.nic.in/sites/ pdf.

Chandran, P.C., Pandian, S.J., Kamal, R. and Dey, A. 2019. Socio-economic status and system of farming practices with Diara buffaloes in the middle gangetic plains of Bihar, India. Buffalo Bull., 38(3): 469-483.

Gubbawar, S.G., Shelke, R.R., Chavan, S.D. and Munnarwar, S.D. 2012. Studies on feeding and housing management with economic performance of Gaolao strain of Nagpuri buffalo. Asian J. Anim. Sci., 7(1): 40-47.

Gupta, D.C., Suresh, A. and Mann, J.S. 2008. Management practices and productivity status of cattle and buffaloes in Rajasthan. Indian J. Anim. Sci., 78(7): 769-774.

https://www.timeanddate.com/weather/ India

Jayashankar, M.R. 2005. Genetic investigations in gowli buffaloes of Karnataka. Ph.D thesis (Animal Genetics and Breeding). Karnataka Veterinary Animal and Fisheries Sciences University, Bidar.

Kalyankar, S.D., Chavan, A.A., Khedkar, C.D. and Kalyankar, S.P. 2008. Studies on management practices of buffaloes in different agro-climatic zones of Maharashtra. Indian J. Anim. Res., 42(3): 157-163.

Kurrey, S. 2015. Characterization of local buffaloes of Chhattisgarh plains. M.V.Sc thesis (Animal Genetics and Breeding). Chhattisgarh Kamdhenu Vishwavidyalaya, Durg.

Sethi, R.K. and Kala, S.N. 2005. Buffalo wealth and genetic improvement programmes in India. In: $8^{\text {th }}$ National Conference on Animal Genetics and Breeding, New Delhi, pp. 51-59. 